\title{
Process-oriented modelling to identify main drivers of erosion-induced carbon fluxes
}

\author{
Florian Wilken ${ }^{1,2,3}$, Michael Sommer ${ }^{3,4}$, Kristof Van Oost ${ }^{5}$, Oliver Bens ${ }^{6}$, and Peter Fiener ${ }^{1}$ \\ ${ }^{1}$ Institute for Geography, Universität Augsburg, Augsburg, Germany \\ ${ }^{2}$ Chair of Soil Protection and Recultivation, Brandenburg University of Technology Cottbus-Senftenberg, \\ Cottbus, Germany \\ ${ }^{3}$ Institute of Soil Landscape Research, Leibniz Centre for Agricultural Landscape Research ZALF e.V., \\ Müncheberg, Germany \\ ${ }^{4}$ University of Potsdam, Institute of Earth and Environmental Sciences, Potsdam, Germany \\ ${ }^{5}$ Earth \& Life Institute, TECLIM, Université catholique de Louvain, Louvain-la-Neuve, Belgium \\ ${ }^{6}$ Helmholtz Centre Potsdam GFZ German Research Centre for Geosciences, Potsdam, Germany
}

Correspondence to: Peter Fiener (peter.fiener@geo.uni-augsburg.de)

Received: 24 October 2016 - Discussion started: 23 November 2016

Revised: 8 March 2017 - Accepted: 28 March 2017 - Published: 5 May 2017

\begin{abstract}
Coupled modelling of soil erosion, carbon redistribution, and turnover has received great attention over the last decades due to large uncertainties regarding erosion-induced carbon fluxes. For a process-oriented representation of event dynamics, coupled soil-carbon erosion models have been developed. However, there are currently few models that represent tillage erosion, preferential water erosion, and transport of different carbon fractions (e.g. mineral bound carbon, carbon encapsulated by soil aggregates). We couple a process-oriented multi-class sediment transport model with a carbon turnover model (MCST-C) to identify relevant redistribution processes for carbon dynamics. The model is applied for two arable catchments (3.7 and $7.8 \mathrm{ha}$ ) located in the Tertiary Hills about $40 \mathrm{~km}$ north of Munich, Germany. Our findings indicate the following: (i) redistribution by tillage has a large effect on erosion-induced vertical carbon fluxes and has a large carbon sequestration potential; (ii) water erosion has a minor effect on vertical fluxes, but episodic soil organic carbon (SOC) delivery controls the long-term erosion-induced carbon balance; (iii) delivered sediments are highly enriched in SOC compared to the parent soil, and sediment delivery is driven by event size and catchment connectivity; and (iv) soil aggregation enhances SOC deposition due to the transformation of highly mobile carbon-rich fine primary particles into rather immobile soil aggregates.
\end{abstract}

\section{Introduction}

Soil organic carbon (SOC) is the largest terrestrial carbon (C) pool and has been identified as a cornerstone for the global C cycle. Globally, approx. $1400 \mathrm{Pg} \mathrm{C}$ is stored in the upper meter of soil, with approx. $700 \mathrm{Pg} \mathrm{C}$ in the upper $0.3 \mathrm{~m}$ (Hiederer and Köchy, 2011). As a result, exchange rates between soil and the atmosphere are a major concern with regards to climate change (Polyakov and Lal, 2004a). Earth system model-based estimates for terrestrial $\mathrm{C}$ storage in the year 2100 vary widely, ranging from a sink of approx. $8 \mathrm{Pg} \mathrm{Cyr}^{-1}$ to a source of approx. $6 \mathrm{Pg} \mathrm{Cyr}^{-1}$ (Friedlingstein et al., 2014). This large uncertainty might even increase if process levels that are at this point not yet implemented in current models are taken into account (Doetterl et al., 2016). One such process is the lateral redistribution of SOC via erosion processes and the effect this has on vertical $\mathrm{C}$ fluxes. Global estimates of erosion-induced $\mathrm{C}$ fluxes show conflicting results, ranging from a source of $1 \mathrm{PgC}^{-1}$ to a sink of the same magnitude (for recent reviews see Doetterl et al., 2016; Kirkels et al., 2014). The main reasons for these large differences are a lack of appropriate data (Prechtel et al., 2009), oversimplified modelling approaches that ignore im- 
portant processes, and differences in measuring approaches, e.g. extrapolating from arable plots (Hooke, 2000; Myers, 1993; Pimentel et al., 1995) vs. measuring continental delivery in river systems (Berhe et al., 2007; Wilkinson and McElroy, 2007).

Most challenging in developing and especially testing models that couple process-oriented SOC redistribution with SOC dynamics are the different spatial and temporal scales of the processes at play (Doetterl et al., 2016). Processoriented erosion models need event-based data to be validated, while SOC dynamics can hardly be observed on timescales smaller than several decades. Consequently, most existing models that couple soil erosion and SOC turnover processes are based on long-term, USLE-type erosion models that ignore event dynamics. The most widespread of these is SPEROS-C, which was applied on scales ranging from micro- to mesoscale catchments (Fiener et al., 2015; Nadeu et al., 2015; Van Oost et al., 2005b).

The conventional approach to modelling coupled soil erosion and SOC turnover is to treat SOC as a stable part of the bulk parent soil and statistically model (long-term) erosion. However, this approach is likely to lead to biased estimates of both water-erosion-induced SOC redistribution and its effect on vertical C fluxes. Numerous studies have shown that the transport of SOC is selective (Schiettecatte et al., 2008), controlled by event characteristics (Sharpley, 1985; Van Hemelryck et al., 2010) and soil aggregation (Hu and Kuhn, 2014, 2016). The enrichment of SOC during transport has been explicitly addressed by a few modelling studies, using different approaches (Fiener et al., 2015; Lacoste et al., 2015). The effects of tillage erosion on vertical $\mathrm{C}$ fluxes have not yet been evaluated in detail, although a representation has been accounted for in some modelling studies (Lacoste et al., 2015; Van Oost et al., 2005a).

The aim of this study is to couple a spatially distributed, process-oriented and event-based water erosion model with a tillage erosion model and a SOC turnover model in order to analyse the importance of individual erosion processes in the erosion-induced $\mathrm{C}$ balance of agricultural catchments. The study intends to identify relevant processes that should be implemented in less data-demanding, more parsimonious models.

\section{Materials and methods}

\subsection{Test site}

The test site is located about $40 \mathrm{~km}$ north of Munich in the Tertiary Hills, an intensively used agricultural area in southern Germany. The site consists of two small arable catchments $\left(48^{\circ} 29^{\prime} \mathrm{N}, 11^{\circ} 26^{\prime} \mathrm{E}\right.$; Fig. 1), catchments $\mathrm{C} 1$ and $\mathrm{C} 2$, covering an area of 3.7 and 7.8 ha, respectively. The rolling topography ranges from 454 to $496 \mathrm{~m}$ above sea level with a mean slope of $4.2^{\circ}\left( \pm 0.6^{\circ}\right)$ for catchment $\mathrm{C} 1$ and $5.3^{\circ}$ $\left( \pm 1.7^{\circ}\right)$ for catchment $\mathrm{C} 2$. The soil landscape is character- ized by Cambisols and Luvisols (partly redoximorphic), both developed from loess. Furthermore, Colluvic Regosols have developed in depressional areas due to long-term soil translocation processes. In both catchments, the dominant topsoil textures are loam and silty loam with a median grain size diameter between 12.5 and $16.0 \mu \mathrm{m}$ (Sinowski and Auerswald, 1999). The average SOC content of the Ap horizons is $3.7 \mathrm{~kg} \mathrm{~m}^{-2}$. The mean annual temperature and precipitation is $8.4^{\circ} \mathrm{C}$ and $834 \mathrm{~mm}$, respectively (measured 1994 to 2001 ). Agricultural management at the research farm is dedicated to soil conservation: the main cropping principle is to keep soil covered by vegetation or residues as long as possible (Auerswald et al., 2000). The crop rotation during the project was winter wheat (Triticum aestivum L.) - maize (Zea mays L.) winter wheat - potato (Solanum tuberosum L.). This crop rotation allowed for the cultivation of mustard (Sinapis alba L.) cover crops before each row crop (i.e. potato and maize). For implementation, potato ridges were formed before mustard sowing and, later, potato was directly sown into the ridges covered by winterkilled mustard. Maize, on the other hand, was directly sown into the winterkilled mulched mustard (Auerswald et al., 2000). For the established mulch tillage system, the main soil tillage operation was performed with a chisel cultivator (tillage depths approx. $0.2 \mathrm{~m}$ ). To avoid soil compaction and depressions, which could potentially induce concentrated runoff, wide and low-pressure tires were used on all farming machines (e.g. Fiener and Auerswald, 2007b). Catchment $\mathrm{C} 1$ drains one large field with an approx. 2-3 m wide grass filter strip along its downslope border, whereas catchment $\mathrm{C} 2$ consists of two fields draining into an approx. $300 \mathrm{~m}$ long and 30-40 m wide grassed waterway (Fig. 1).

\subsection{Model description}

For our study, we coupled three different models: (i) the process-oriented Multi-Class Sediment Transport Model (Fiener et al., 2008; Van Oost et al., 2004; Wilken et al., 2017), a spatially distributed and event-based water erosion model with a specific emphasis on grain size selectivity using the Hairsine and Rose equations (Hairsine et al., 1992; Hairsine and Rose, 1991); (ii) a tillage erosion model following a diffusion-type equation adopted from Govers et al. (1994), which derives tillage erosion from topography and tool-specific tillage erosion coefficients; and (iii) the Introductory Carbon Balance Model (ICBM; Andrén and Kätterer, 1997; Kätterer and Andrén, 2001), which models SOC turnover. The ICBM calculates yearly SOC dynamics using two SOC pools ("young" and "old") and four C fluxes (C input from plants, mineralization from the young and the old pool, and humification). Both the tillage erosion and ICBM model were adapted from SPEROS-C, which couples annual water erosion (based on the RUSLE; Renard et al., 1996), tillage erosion and SOC turnover (Fiener et al., 2015; Nadeu et al., 2015; Van Oost et al., 2005b). In the following, we describe only those features of the coupled MCST-C 


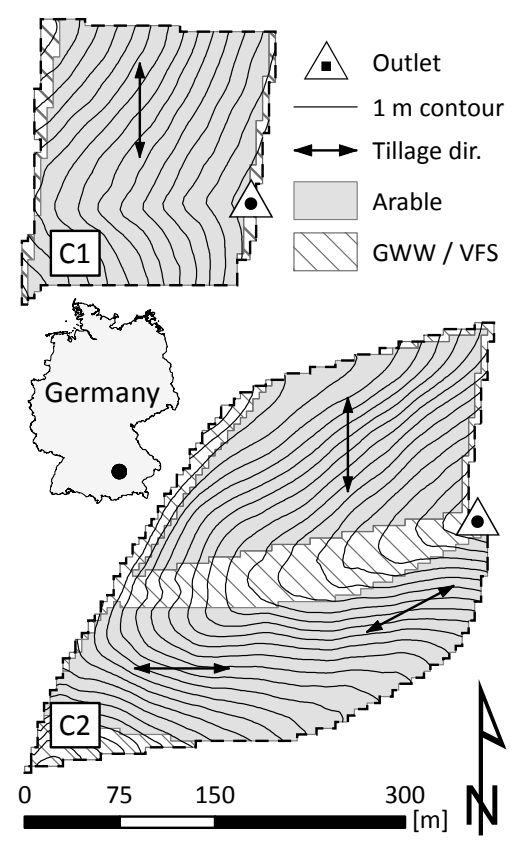

Figure 1. Land use, topography, and tillage direction for modelled catchments $\mathrm{C} 1$ and $\mathrm{C} 2$. In catchment $\mathrm{C} 2$, a grassed waterway (GWW) is located along the thalweg, while vegetated filter strips (VFS) are located along the upslope and downslope field borders.

model (Multi-Class Sediment Transport and Carbon dynamics model) that had to be adapted in order to couple the models or for the introduction of SOC-specific transport mechanisms. An overview of the main model concepts of MCST-C is given in Fig. 2. For more details regarding the three coupled models and processes modelled therein, we refer the reader to the original publications (see above).

\subsection{Representation of grain-size-specific soil and associated SOC}

The representation of soil texture and SOC in the model is three-dimensional. The horizontal distribution of grain-sizespecific soil and SOC is grid-based, while the vertical distribution is represented by ten $10 \mathrm{~cm}$ layers. The two uppermost layers are assumed to be homogeneously mixed due to tillage. The grain size distribution is represented in 14 primary particle classes, described by class median particle diameter, particle density, and the class proportion relative to the bulk soil $\left(\mathrm{kg} \mathrm{kg}^{-1}\right)$. The median class diameter is calculated by a logarithmic function that takes grain diameter class boundaries into account (Scheinost et al., 1997). The standard procedure (e.g. sieve-pipette method; Casagrande, 1934; DIN, 2002) to determine grain size distributions destroys soil aggregates in a pre-processing step and therefore only represents the primary particle distribution. However, soil aggregation has a large effect on the fall velocity distribution of soils and reduces the transport distance of SOC-rich material (Hu and Kuhn, 2014, 2016). Therefore, to account for soil aggregation, two water-stable aggregate classes have been introduced following the hierarchy model of Oades (1984), which describes microaggregate formation inside macroaggregates: silt-sized small microaggregates $(6.3-53 \mu \mathrm{m}$, median diameter (D50): $18 \mu \mathrm{m}$; Tisdall and Oades, 1982) and microaggregates $(53-250 \mu \mathrm{m}, \mathrm{D} 50$ : $115 \mu \mathrm{m}$; Six et al., 2002). In model parametrization, the small microaggregates are exclusively formed out of primary particles with diameters less than $6.3 \mu \mathrm{m}$, whereas microaggregates are formed from those with diameters less than $53 \mu \mathrm{m}$ (i.e. the lower diameter boundary of the aggregate class). As a result, aggregation causes a certain number of primary particles to be moved into the aggregate classes. Hence, the absolute amount of soil aggregation is controlled by the availability of fine primary particles, i.e. sandy soils are less aggregated compared to clayey soils. Macroaggregates (250-2000 $\mu \mathrm{m})$ are neglected since they are rather immobile during selective interrill erosion and are assumed to break into smaller aggregates during extreme events with highprecipitation kinetic energies (Legout et al., 2005; Oades and Waters, 1991; Tisdall and Oades, 1982). Furthermore, particulate organic matter (POM) is not treated as an individual class, as POM is assumed to be predominantly encapsulated within soil aggregates (Beuselinck et al., 2000; Wang et al., 2013; Wilken et al., 2017).

SOC transport is associated with various primary particle and aggregate classes. Based on the literature (Doetterl et al., 2012; Von Lützow et al., 2007), it is assumed that mineral bound SOC is primarily attached to fine particles $(<6.3 \mu \mathrm{m})$ or included in soil aggregates. To keep the mass balance, SOC in water-stable aggregates is allocated based on the SOC content of the primary particles that form these aggregates. This leads to a conservative estimate of SOC in aggregates, as measurements show that aggregates tend to encapsulate more $\mathrm{C}$ than found attached to mineral primary particles (Doetterl et al., 2012). As small microaggregates in the model consist solely of primary particles with diameters less than $6.3 \mu \mathrm{m}$, their $\mathrm{C}$ content equals that of the fine primary particles. Microaggregates show a somewhat smaller C content, since the larger primary particles from which they are also made tend to have less associated SOC.

\subsection{Continuous tracking of catchment dynamics}

In its original version, the MCST model treats events individually without considering changes caused by previous events. For a continuous application, the water erosion module of MCST-C simulates single events and keeps track of the following redistribution related changes in the catchment: spatial and vertical changes in (i) the grain size distribution and (ii) SOC content and (iii) the development of a rill network, which remains until the next tillage operation. A layer-specific mixture module continuously updates for spatial changes in the vertical grain size distribution and its asso- 


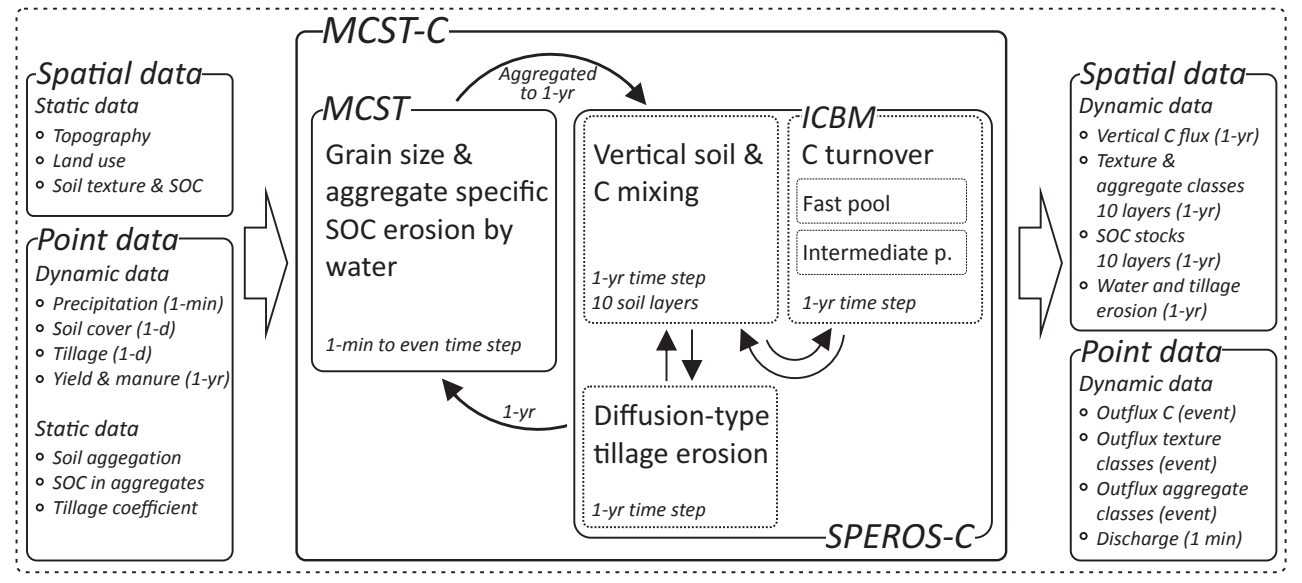

Figure 2. Modelling scheme of the Multi-Class Sediment Transport and Carbon dynamics model (MCST-C).

ciated SOC content, changes which are caused by selective redistribution of water and non-selective tillage erosion. In the case of net deposition, new material with a different grain size distribution is added to the top of the plough horizon (layer 1 and 2). Subsequently, the grain size distribution of the plough layer is mixed and assumed to be homogeneous. Furthermore, deposition leads to an upward movement of the layer borders such that soil material from the plough layer becomes incorporated into the subsoil layers. Any $\mathrm{C}$ content moving below $1 \mathrm{~m}$ depth is summarized and assumed to be stable in time. In contrast, erosion lifts new material from the subsoil horizons upwards. Assuming that the deepest horizon represents the original loess, the properties of uplifted subsoil remain constant, delivering infinite material of the same grain size distribution and $\mathrm{C}$ content.

\subsection{Model validation}

For a truly rigorous validation of MCST-C, there are numerous long-term data requirements: event-based data for surface runoff, sediment delivery and SOC delivery, long-term data regarding changes in spatially distributed SOC stocks, spatially distributed $\mathrm{C}$ loss and gain due to crop harvesting, and $\mathrm{C}$ input via plants and manure application. In addition to these validation data requirements, model input data would also be required over decades for a long-term validation. The research project (Auerswald et al., 2000) which is the basis of this study provided a very comprehensive database. However, continuous monitoring was "only" carried out for 8 years (1994 to 2001), and SOC inventories span roughly a decade (first inventory in 1990/91, second in 2001). Therefore, measured changes in SOC stocks are too small to be used for a long-term model validation (requires approx. 50 years; see implementation).

In consequence, we only use the measured continuous event-based surface runoff and sediment delivery from catchment $\mathrm{C} 1$ to validate the modelled erosion. The runoff was collected at the lowest point of the catchment (Fig. 1), which was bordered by a small earthen dam. From the dam, the runoff was transmitted via an underground tile outlet (diameter $0.29 \mathrm{~m}$ ) to a measuring system consisting of a Coshoctontype wheel runoff sampler (for details regarding the procedure and the precision of the measurements see Fiener and Auerswald, 2003). Corresponding precipitation was measured using a tipping bucket rain gauge of $0.2 \mathrm{~mm}$ volume resolution. To determine single erosion events, the precipitation data are filtered in two steps: first, all events with cumulative precipitation $>5 \mathrm{~mm}$ and without a $6 \mathrm{~h}$ gap in recorded precipitation are considered single erosion events. Second, we included all the largest events accounting for $90 \%$ of total observed runoff. The model is not able to predict erosion under soil frost; hence, winter events, indicated by air temperatures below zero, are removed.

As the original MCST model was previously tested in catchment C1 (Fiener et al., 2008), we did not explicitly calibrate the surface runoff and erosion model. Instead, observed runoff and sediment delivery data was used to test whether our changes to the model still result in a reasonable model performance.

\subsection{Model implementation}

To run and test MCST-C, a variety of measured input data and parameters are required. This input data are partly calculated from measured data at the research farm and partly taken from literature (Table 1; Fig. 2). To model surface runoff and erosion, the most important input data requirements are (i) precipitation, measured at two meteorological stations about 100 to $300 \mathrm{~m}$ from the catchments using $0.2 \mathrm{~mm}$ tipping buckets, (ii) a lidar $5 \mathrm{~m} \times 5 \mathrm{~m}$ digital elevation model, (iii) soil data taken from a $50 \mathrm{~m} \times 50 \mathrm{~m}$ raster sampled during the soil survey in 1990/91 (Sinowski et al., 1997), and (iv) soil cover data, measured biweekly during the vegetation period, monthly in autumn and spring, and before 
Table 1. Main input data and parameters used in the Multi-Class Sediment Transport and Carbon dynamics model (MCST-C).

\begin{tabular}{|c|c|c|c|}
\hline Description & Unit & Temporal resolution & Range/value \\
\hline Digital elevation model & $\mathrm{m}$ & static & $(5 \mathrm{~m} \times 5 \mathrm{~m}) 454-496$ \\
\hline Land use & - & daily & - \\
\hline Soil cover & $\%$ & biweekly & $0-100$ \\
\hline Curve number per crop to be modified by cover and soil crusting & - & daily & $38-88$ \\
\hline Tillage roughness and direction & $\mathrm{m}$ & vegetation period & $0-0.25$ \\
\hline Hydraulic roughness arable land & $\mathrm{s} \mathrm{m}^{-1 / 3}$ & biweekly & $0.016-0.101$ \\
\hline Hydraulic roughness grass strip & $\mathrm{s} \mathrm{m}^{-1 / 3}$ & static & 0.20 \\
\hline Yield & $\mathrm{kg} \mathrm{m}^{-2}$ & at harvest & $0.6-4.3$ \\
\hline Manure & $\mathrm{kg} \mathrm{C} \mathrm{m}^{-2}$ & at fertilization & $0-0.13$ \\
\hline Tillage operation & - & daily & - \\
\hline Soil bulk density & $\mathrm{kg} \mathrm{m}^{-3}$ & static & 1350 \\
\hline Initial texture & $\mu \mathrm{m}$ & static & $0.04-2000$ \\
\hline Primary particle density & $\mathrm{kg} \mathrm{m}^{-3}$ & static & 2650 \\
\hline Small microaggregate density & $\mathrm{kg} \mathrm{m}^{-3}$ & static & 1300 \\
\hline Microaggregate density & $\mathrm{kg} \mathrm{m}^{-3}$ & static & 1300 \\
\hline Small microaggregate median diameter & $\mu \mathrm{m}$ & static & 18 \\
\hline Microaggregate median diameter & $\mu \mathrm{m}$ & static & 115 \\
\hline
\end{tabular}

and after each soil management operation (1993-1997). A tillage transport coefficient $\left(k_{\mathrm{til}}\right)$ of $169 \mathrm{~kg} \mathrm{~m}^{-1} \mathrm{yr}^{-1}$ was utilized for contour tillage by a chisel, following Van Muysen et al. (2000). For SOC redistribution and modelling of vertical C fluxes, the most important model inputs were yields and manure application, a topsoil SOC map $\left(12.5 \times 12.5 \mathrm{~m}^{2}\right.$; Sinowski et al., 1997), and assumptions regarding the allocation of $\mathrm{C}$ to different texture classes and in different aggregates. As texture and aggregate $\mathrm{C}$ allocation was not measured, we took measured data from Doetterl et al. (2012) and scaled these measurements according to the available bulk SOC (see Sect. 2.3: Representation of grain-size-specific soil and SOC). The parameters for the $\mathrm{C}$ turnover model are taken from Dlugoß et al. (2012), who worked under similar environmental conditions with loess-derived soils in a small catchment in western Germany. The $\mathrm{C}$ turnover decline with depth was determined by an inverse modelling approach and found a mean turnover rate of $0.268 \mathrm{yr}^{-1}$ for the young pool and $0.002 \mathrm{yr}^{-1}$ for the old pool over the $1 \mathrm{~m}$ soil profile. Further details regarding the monitoring data are given in Fiener and Auerswald (2003, 2007b) and Fiener et al. (2008).

As indicated above, it is difficult, if not impossible, to identify erosion-induced changes in SOC and vertical C fluxes if measurements or modelling efforts do not cover decadal time spans. Therefore, a 50-year synthetic input data set and parameter set was created for MCST-C in order to analyse $C$ dynamics. This data set is based on the 8 years of measured data used to validate the erosion component of the model. First, a time series of precipitation was established by randomly choosing the data of one of the eight measured years (see Sect. 2.5: Model validation) and applying it for the first 42 years of the time series. This was followed by the original 8 measured years to reach the total of 50 years.
Next, this precipitation time series was combined with synthetic land use and soil management data representing two full crop rotations (1994 to 2001), which were repeatedly used for all 50 years. This combination leads to a wide variety of precipitation events (time step $1 \mathrm{~min}$ ) occurring for different daily soil covers by vegetation as a major driver of soil erosion. In contrast to the erosion dynamics, $\mathrm{C}$ inputs via plants and manure are repeated every 8 years, which ignores any potential change in management and yields within the modelling period. The synthetic input data were applied for both catchments for the purpose of comparability.

\subsection{Analysis of process-specific, erosion-induced C fluxes}

Various model setups were chosen (Table 2) to analyse the effects of different erosion processes upon lateral SOC redistribution and the resulting vertical $C$ fluxes. All of these model runs were compared to the 50-year reference run that was validated for the 8-year monitoring phase at the research farm (1994-2001). In general, we tested the effect of a number of water erosion processes and compared the relevance of water vs. tillage erosion. Firstly, the critical shear stress of rill initiation $\left(\tau_{\text {crit }}\right)$ was varied by $\pm 50 \%$ in comparison to its reference run value $(0.9 \mathrm{~Pa})$ in order to change the proportion of interrill vs. rill erosion, whereas interrill erosion is a selective SOC transport process and rill erosion is unselective. The reference run value for $\tau_{\text {crit }}$ was derived from flume experiments in loamy, loess-derived soils (Giménez and Govers, 2002) similar to those found at the test site. Next, the aggregation level was varied in an analogous way to modify the allocation of soil primary particles into the small microaggregate and microaggregate classes (Fig. 3). In another model 
Table 2. Model parametrization to analyse the effects of different erosion processes upon C fluxes. Model runs are abbreviated as follows: reference run (Ref), without tillage erosion ( Til $1_{\text {off }}$ ), water erosion without grain size selectivity $\left(\mathrm{GS}_{\text {off }}\right)$, high threshold for rill initiation $\left(\mathrm{Ril}_{\mathrm{lo}}\right)$, low threshold for rill initiation $\left(\mathrm{Ril}_{\mathrm{hi}}\right)$, without soil aggregation $\left(\mathrm{Agg}_{\mathrm{off}}\right)$, low soil aggregation $\left(\mathrm{Agg}_{\mathrm{lo}}\right)$, high soil aggregation $\left(\mathrm{Agg}_{\mathrm{hi}}\right)$, without water erosion $\left(\mathrm{Wa}_{\mathrm{off}}\right)$, low tillage erosion $\left(\mathrm{Til}_{\mathrm{lo}}\right)$, and high tillage erosion $\left(\mathrm{Til}_{\mathrm{hi}}\right)$.

\begin{tabular}{|c|c|c|c|c|c|c|c|c|c|c|c|c|}
\hline Processes & Parameter (unit) & Ref & $\mathrm{Til}_{\text {off }}$ & $\mathrm{GS}_{\text {off }}$ & $\mathrm{Ril}_{\text {lo }}$ & $\mathrm{Ril}_{\mathrm{hi}}$ & $\mathrm{Agg}_{\mathrm{off}}$ & $\mathrm{Agg}_{10}$ & $\mathrm{Agg}_{\mathrm{hi}}$ & $\mathrm{Wa}_{\text {off }}$ & $\mathrm{Til}_{\mathrm{lo}}$ & $\mathrm{Til}_{\mathrm{hi}}$ \\
\hline \multicolumn{13}{|l|}{ Water erosion } \\
\hline with vs. w/o tillage erosion & $(-)$ & $+^{\mathrm{a}}$ & - & + & + & + & + & + & + & + & + & + \\
\hline with vs. w/o grain size selectivity & $(-)$ & + & + & - & + & + & + & + & + & + & + & + \\
\hline varying rill/interrill erosion & $\tau_{\text {crit }} \mathrm{b}(\mathrm{Pa})$ & 0.9 & 0.9 & 0.9 & 1.35 & 0.45 & 0.9 & 0.9 & 0.9 & 0.9 & 0.9 & 0.9 \\
\hline varying small micro \& microaggregates & $(\%)$ & 60 & 60 & 60 & 60 & 60 & 0 & 30 & 90 & 60 & 60 & 60 \\
\hline \multicolumn{13}{|l|}{ Tillage erosion } \\
\hline with vs. w/o water erosion & $(-)$ & + & + & + & + & + & + & + & + & - & + & + \\
\hline varying tillage intensity & $k_{\mathrm{til}}{ }^{\mathrm{c}}\left(\mathrm{kg} \mathrm{m}^{-1} \mathrm{yr}^{-1}\right)$ & 169 & 0 & 169 & 169 & 169 & 169 & 169 & 169 & 169 & 85 & 254 \\
\hline
\end{tabular}

${ }^{\mathrm{a}}+$ and - indicate whether a process is modelled or not; ${ }^{\mathrm{b}}$ critical shear stress for rill initiation; ${ }^{\mathrm{c}}$ tillage erosion coefficient.

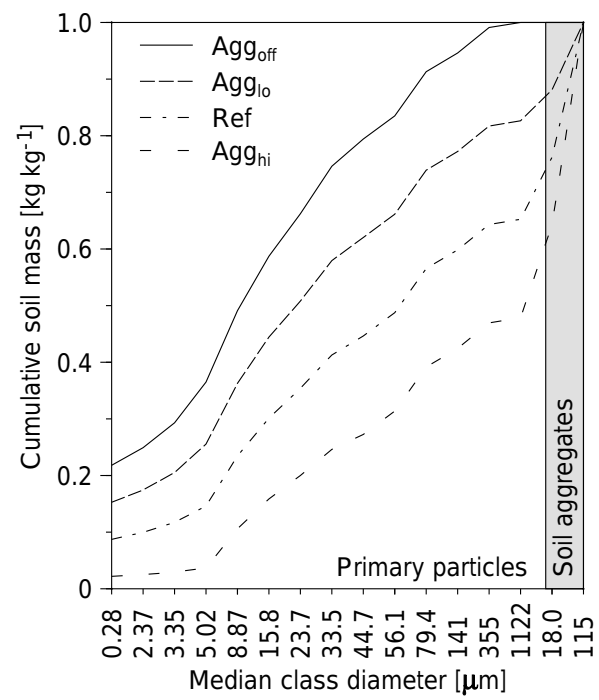

Figure 3. Median class diameter distribution (14 primary particle and 2 aggregate classes) in the plough layer assuming different aggregation levels, as described in Table 2 .

run, grain size selectivity was switched off in order to produce a similar behaviour to more parsimonious models which only erode bulk soil (Table 2). To analyse the sensitivity of C fluxes to water and tillage erosion, we first compared model runs with pure water or pure tillage erosion. Secondly, we varied the reference run $k_{\mathrm{til}}$ coefficient of $169 \mathrm{~kg} \mathrm{~m}^{-1} \mathrm{yr}^{-1}$ by $\pm 50 \%$. All model runs altered only a single parameter, with all other parameters retaining their reference run values. Parameter variations and the abbreviations for each of the model runs are given in Table 2.

\subsection{Analysis of erosion-induced C fluxes}

To compare vertical $\mathrm{C}$ fluxes from erosional and depositional sites, the corresponding total and mean $\mathrm{C}$ flux was calculated on an annual basis. To isolate the $\mathrm{C}$ fluxes that result
Table 3. Model performance, as described by the Nash-Sutcliffe efficiency (NSE; Nash and Sutcliffe, 1970), root mean square error (RMSE), coefficient of determination $\left(R^{2}\right)$, and Spearman's rank correlation coefficient (RHO).

\begin{tabular}{lcrrr}
\hline & NSE & RMSE & $R^{2}$ & RHO \\
\hline Runoff & 0.83 & $5.6 \mathrm{~mm}$ & 0.94 & 0.89 \\
Sediment delivery & 0.92 & $165 \mathrm{~kg} \mathrm{ha}^{-1}$ & 0.95 & 0.71 \\
\hline
\end{tabular}

solely from erosion processes, we first calculate all vertical $\mathrm{C}$ fluxes excluding erosion processes and then subtract these from the vertical $\mathrm{C}$ fluxes including erosion processes. In the following results section, positive $\mathrm{C}$ fluxes indicate an erosion-induced $\mathrm{C}$ gain for the catchment (input to the soil), while negative fluxes indicate an erosion-induced loss (from soil to the atmosphere or SOC delivery from the catchment by runoff). Subsequently, erosional and depositional sites were spatially subdivided and an average vertical $\mathrm{C}$ flux in $\mathrm{kg} \mathrm{C} \mathrm{m}^{-2}$ was calculated. Finally, the erosion-induced C balance of the catchment was calculated as the sum of the total vertical C flux and laterally delivered SOC.

\section{Results}

\subsection{Validation}

A number of goodness-of-fit parameters (Table 3 ) indicate a sufficient model performance to simulate event runoff and sediment delivery for the 8-year observation period. The Nash-Sutcliffe efficiency and coefficient of determination for runoff $\left(\mathrm{NSE}=0.83 ; R^{2}=0.94\right)$ and sediment delivery $\left(\mathrm{NSE}=0.92 ; R^{2}=0.95\right)$ are particularly satisfactory. However, a root mean square error of $165 \mathrm{~kg} \mathrm{ha}^{-1}$ for sediment delivery indicates difficulties in predicting some small events. 

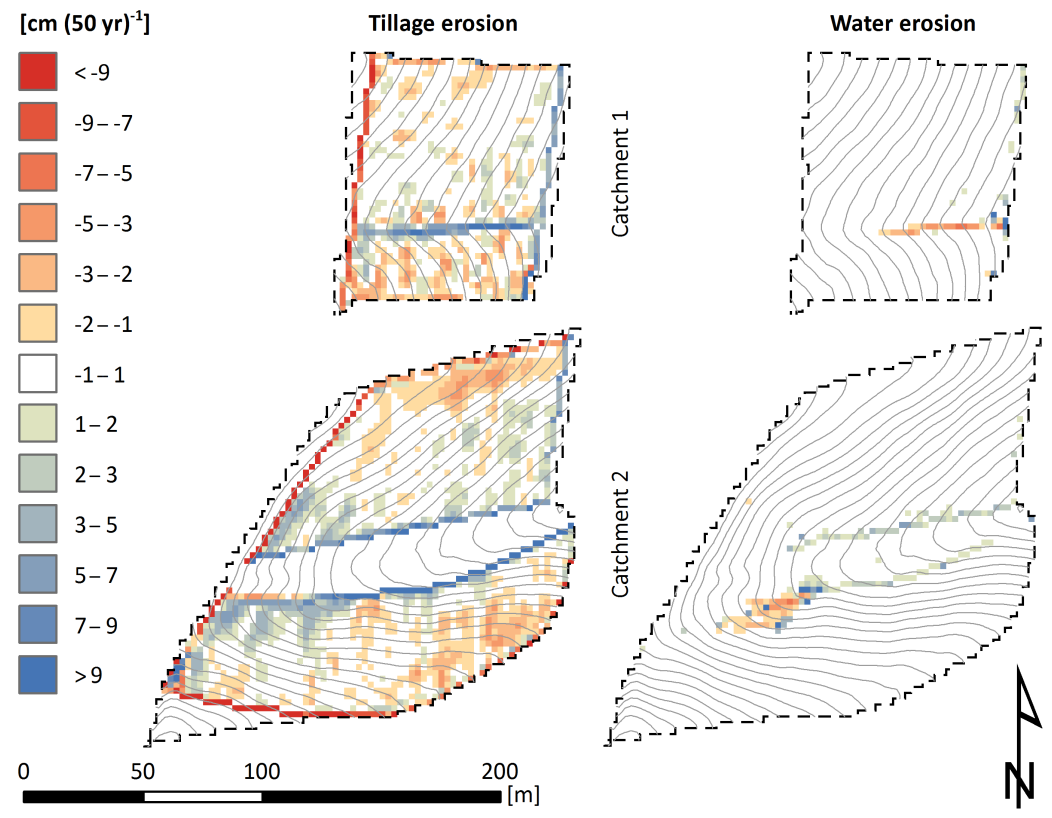

Figure 4. Spatial patterns of tillage and water erosion for the 50-year simulation period of the reference run.

\subsection{Long-term erosion-induced C fluxes}

The simulated tillage and water erosion shows distinct spatial patterns (Fig. 4). The highest rates of tillage erosion are found along the upslope boundaries of the arable field and on hilltops. The main areas for tillage-induced deposition are at the downslope arable field boundaries and in concavities (Fig. 4). Due to the well-established soil conservation system, water erosion takes place over a much smaller spatial extent and is limited to the main hydrological flow path, while deposition is dominantly found in the vegetated filter strips and grassed waterway (Fig. 4).

The reference run (validated against sediment delivery in catchment C1, 1994-2001) shows positive vertical C fluxes at erosional sites over the 50 -year simulation period, with a cumulative flux of $40 \mathrm{~g} \mathrm{~m}^{-2}(50 \mathrm{yr})^{-1}$ in $\mathrm{C} 1$ and $59 \mathrm{~g} \mathrm{~m}^{-2}$ $(50 \mathrm{yr})^{-1}$ in $\mathrm{C} 2$ (Fig. 5: Ero1, Ero2). The depositional C fluxes show a cumulative $\mathrm{C}$ loss of $-27 \mathrm{~g} \mathrm{~m}^{-2}(50 \mathrm{yr})^{-1}$ and $-30 \mathrm{~g} \mathrm{~m}^{-2}(50 \mathrm{yr})^{-1}$ for $\mathrm{C} 1$ and $\mathrm{C} 2$, respectively (Fig. 5: Dpo1, Dpo2). Lateral SOC delivery is mainly driven by three heavy erosion events causing 58 and $53 \%$ of the total SOC delivery in $\mathrm{C} 1$ and $\mathrm{C} 2$, respectively. The total SOC delivery in $\mathrm{C} 1$ is $-15.6 \mathrm{~g} \mathrm{~m}^{-2}(50 \mathrm{yr})^{-1}$ and in $\mathrm{C} 2$ is $-6.5 \mathrm{~g} \mathrm{~m}^{-2}$ $(50 \mathrm{yr})^{-1}$ (Fig. 5: Del1, Del2). In C1, the source function of lateral SOC delivery exceeds the sink function of vertical SOC sequestration and leads to a net $C$ loss of $-5.7 \mathrm{~g} \mathrm{~m}^{-2}$ $(50 \mathrm{yr})^{-1}$ (Fig. 5: Bal1, Bal2). In contrast, catchment $\mathrm{C} 2$ is a net $C$ sink of $4.6 \mathrm{~g} \mathrm{~m}^{-2}(50 \mathrm{yr})^{-1}$.

The event-based SOC enrichment in delivered sediments, compared to parent soil, ranges from 1.1 to 2.7 (2.4 mean) for $\mathrm{C} 1$ and from 2.5 to 2.7 (2.7 mean) for $\mathrm{C} 2$ over the 50-year time span (Fig. 6). Subdividing the events into tertiles (33\% parts) according to sediment delivery, the mean enrichment in $\mathrm{C} 1$ is $2.5(n=67)$ for the low tertile (i.e. smallest $33 \%$ of all event-specific sediment delivery masses), $1.4(n=6)$ for the middle tertile, and $1.2(n=2)$ for the high tertile (Fig. 6). In contrast, more or less no variation in SOC enrichment was modelled for C2 (Fig. 6).

\subsection{Importance of individual erosion processes for long-term erosion-induced $\mathrm{C}$ fluxes}

Vertical C fluxes show a large response to changes in the $k_{\text {til }}$ coefficient but a negligible response to varying levels of water erosion (Fig. 5: Ero1, Ero2, Dpo1, Dpo2). Cumulative C flux at erosional and depositional sites is found to be lowest when no tillage ( $\mathrm{Til}_{\text {off }}$ ) is simulated and highest for strong tillage $\left(\mathrm{Til}_{\mathrm{hi}}\right)$. When pure tillage erosion is simulated $\left(\mathrm{Wa}_{\text {off }}\right)$ in catchment $\mathrm{C} 1$, a $\mathrm{C}$ sequestration of $7 \mathrm{~g} \mathrm{~m}^{-2}(50 \mathrm{yr})^{-1}$ is simulated (Fig. 5: Bal1). The majority of processes in catchment $\mathrm{C} 2$ lead to an erosion-induced $\mathrm{C}$ gain for the catchment. The highest $\mathrm{C}$ sequestration in catchment $\mathrm{C} 2$ is found for high tillage erosion ( $\left.\mathrm{Til}_{\mathrm{hi}}: 10.3 \mathrm{~g} \mathrm{~m}^{-2}(50 \mathrm{yr})^{-1}\right)$. In contrast, catchment $\mathrm{C} 2$ acts as a source when there is no tillage (Til $1_{\text {off }}$ : $\left.-4.8 \mathrm{~g} \mathrm{~m}^{-2}(50 \mathrm{yr})^{-1}\right)$, as well as when tillage erosion is low $\left(\right.$ Til $_{\mathrm{lo}}$ : $-0.4 \mathrm{~g} \mathrm{~m}^{-2}(50 \mathrm{yr})^{-1}$; Fig. 5: Bal2).

Lateral SOC delivery is solely caused by water erosion. The model shows its smallest levels of lateral SOC delivery when grain size selectivity is ignored $\left(\mathrm{GS}_{\text {off }}\right)$, and delivered sediments therefore have the same SOC concentration as the parent soil $\left(\mathrm{C} 1:-10 \mathrm{~g} \mathrm{~m}^{-2}(50 \mathrm{yr})^{-1} ; \mathrm{C} 2:-2.4 \mathrm{~g} \mathrm{~m}^{-2}\right.$ $\left.(50 \mathrm{yr})^{-1}\right)$. This effect is less pronounced for catchment $\mathrm{C} 2$ (Fig. 5: Del1, Del2). Catchment C1 shows the largest SOC delivery when the threshold for rill initiation is low (Ril $l_{\text {hi }}$ : 


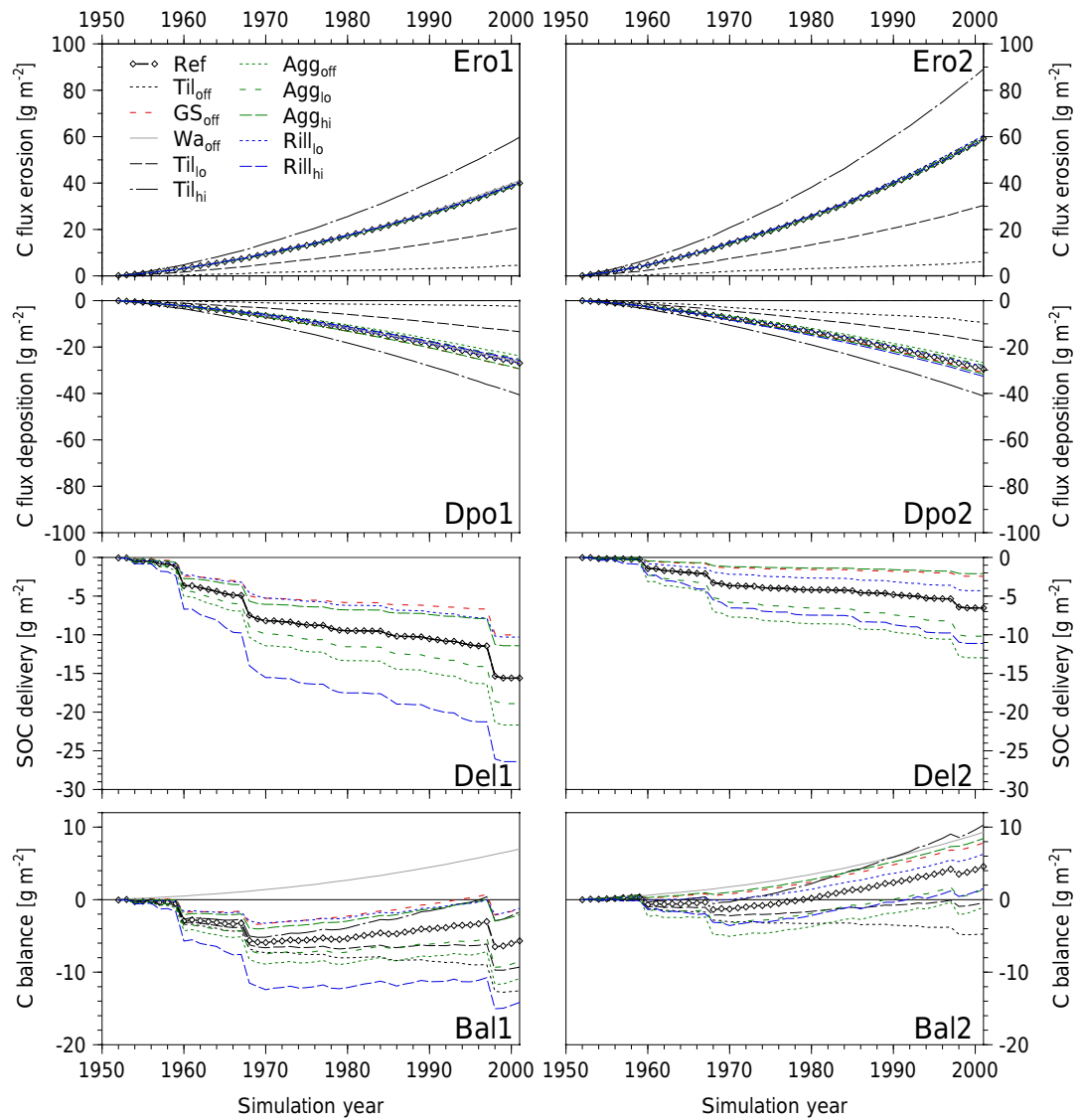

Figure 5. Simulated cumulative vertical C fluxes for erosional (Ero1, Ero2) and depositional (Dpo1, Dpo2) sites, lateral C delivery (Del1, Del2), and catchment $\mathrm{C}$ balance (Bal1, Bal2) for catchment $\mathrm{C} 1$ and $\mathrm{C} 2$. For details regarding the model runs and corresponding abbreviations see Table 2.

$\left.-26.3 \mathrm{~g} \mathrm{~m}^{-2}(50 \mathrm{yr})^{-1}\right)$. In catchment $\mathrm{C} 2$, the highest lateral SOC delivery is achieved when there is assumed to be no soil aggregation $\left(\mathrm{Agg}_{\text {off }}\right.$ : $\left.-13.0 \mathrm{~g} \mathrm{~m}^{-2}(50 \mathrm{yr})^{-1}\right)$. If water erosion is taken into account, catchment $\mathrm{C} 1$ is a net $\mathrm{C}$ source ranging from $1.3\left(\mathrm{GS}_{\text {off }}\right)$ to $14.2\left(\mathrm{Ril}_{\mathrm{hi}}\right) \mathrm{g} \mathrm{m}^{-2}(50 \mathrm{yr})^{-1}$. In contrast, the tillage-induced sequestration potential of catchment $\mathrm{C} 2$ exceeds SOC delivery in most water erosion model runs, leading to a positive erosion-induced $\mathrm{C}$ balance (sink) as long as soil aggregation is included $\left(\mathrm{Agg}_{\text {off }}:-1 \mathrm{~g} \mathrm{~m}^{2}\right.$ $(50 \mathrm{yr})^{-1}$; Fig. 5: Bal1-Bal2).

Variations in SOC enrichment of delivered sediments is generally rather small for all model runs (Fig. 6). The most pronounced effect on SOC enrichment results from different aggregation levels (Agg $\left.{ }_{\text {off }}, \mathrm{Agg}_{\mathrm{lo}}, \mathrm{Agg}_{\mathrm{hi}}\right)$. However, differences in SOC enrichment were much more pronounced between the catchments. While $\mathrm{C} 2$ show high enrichment ratios $(>2.5$ ) for all events, the enrichment ratios strongly decline with increasing event size in $\mathrm{C} 1$ (Fig. 6b-c).

\section{Discussion}

\subsection{Vertical C fluxes}

Tillage erosion dominates the erosion-induced vertical $\mathrm{C}$ fluxes in both catchments. Without water erosion ( $\left.\mathrm{Wa}_{\text {off }}\right)$, total tillage-erosion-induced $\mathrm{C}$ sequestration potential was 7 and $9 \mathrm{~g} \mathrm{~m}^{2}(50 \mathrm{yr})^{-1}$ in catchment $\mathrm{C} 1$ and $\mathrm{C} 2$, respectively. The higher sequestration potential in catchment $\mathrm{C} 2$ results from steeper slopes and more field boundaries, where tillage erosion is most pronounced (Fig. 4). This offsets its smaller relative proportion of arable land. However, this field boundary effect (Fig. 4) might be overestimated as we did not update the digital elevation model during the 50-year simulation period. The response of vertical $\mathrm{C}$ fluxes to changes in tillage erosion strength $\left(\mathrm{Til}_{\mathrm{lo}}\right.$; $\mathrm{Til}_{\mathrm{hi}}$ ) further underlines the dominance of tillage redistribution in determining these fluxes (Fig. 5). This dominance results, in part, from the soil conservation system established at the research farm. Indeed, when compared to conventional soil management practices, water erosion was reduced by roughly a factor of 20 (Fiener and Auerswald, 2007a), while tillage erosion intensity $\left(k_{\mathrm{til}}\right)$ was only reduced by a factor of about 3 (Van Oost et al., 


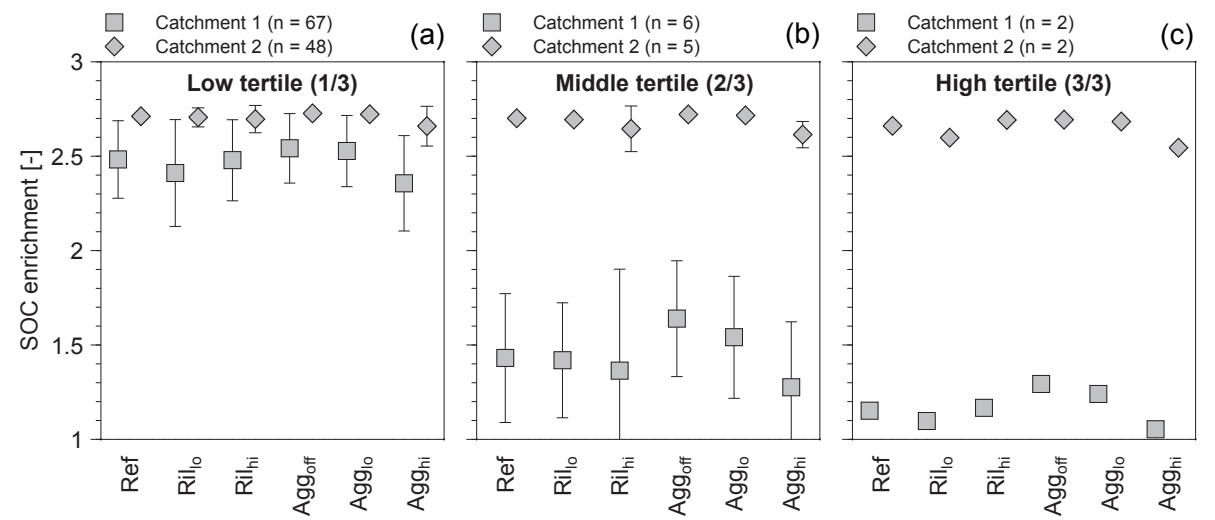

Figure 6. Event-size-specific simulated mean SOC enrichment in delivered sediments of catchment $\mathrm{C} 1$ and $\mathrm{C} 2$. Error bars indicate one standard deviation. Panels (a), (b), and (c) represent the smallest, middle, and largest $33.3 \%$ of all event-specific sediment delivery masses. For details regarding different model runs and abbreviations see Table 2.

2006) as a result of the soil conservation system. However, independent from the soil tillage management, it is obvious that tillage erosion needs to be taken into account for reasonable estimates of vertical erosion-induced $\mathrm{C}$ fluxes on arable land (see also Van Oost et al., 2005a). Moreover, it should be noted that modelling tillage erosion is associated with large uncertainties since it is controlled by a large number of parameters (e.g. tool geometry and type, up-down or contour tillage, speed, depth, soil characteristics; Van Muysen et al., 2000; Van Oost and Govers, 2006). This uncertainty is illustrated by the large range of $k_{\text {til }}$ coefficients which can be found in the literature (e.g. for chisel $k_{\mathrm{til}}: 70$ to $657 \mathrm{~kg} \mathrm{~m}^{-1} \mathrm{yr}^{-1}$; Van Oost and Govers, 2006). Interestingly, different water erosion processes hardly affected the vertical erosion-induced $\mathrm{C}$ fluxes. This is even true for model parametrizations with very pronounced rill erosion $\left(\mathrm{Ril}_{\mathrm{hi}}\right)$ and large sediment fluxes, because rills only affect a small area. Deposition is also restricted to a small number of raster cells (Fig. 4), particularly in the grassed waterway of catchment $\mathrm{C} 2$. The model does not account for changes in $\mathrm{C}$ mineralization at depositional sites that may occur as a result of aggregate breakdown shortly after deposition (Hu et al., 2016; Van Hemelryck et al., 2010, 2011). However, the potential underestimation of $\mathrm{C}$ mineralization at depositional sites is assumed to be small ( $<2 \%$ at a loess site in Belgium; Van Hemelryck et al., 2011). In addition, various drivers of additional $\mathrm{C}$ mineralization at depositional sites have been discussed in literature (soil moisture, crusting and crust recovery, deposition of large macroaggregates; Van Hemelryck et al., 2010, 2011) but there is still a substantial lack in process understanding. At this moment, this issue makes it difficult to transfer the specific experimental results into a modelling framework addressing other environmental conditions.

Overall, to achieve accurate estimates of vertical erosioninduced C fluxes, it seems to be more important to improve the representation of tillage erosion in the model, rather than focusing on detailed process-oriented water erosion modelling, which is less important for vertical C fluxes.

\subsection{Lateral C fluxes}

In contrast to vertical $\mathrm{C}$ fluxes, lateral erosion-induced $\mathrm{C}$ fluxes are substantially affected by a number of eventspecific processes. To assess these processes, a spatially distributed process-oriented modelling approach is needed.

Our synthetic 50-year data set (based on the 1994-2001 observations) produces three large SOC delivery events, representing nearly $60 \%$ of the total SOC delivery in both catchments (Fig. 5: Del1-Del2). This underlines the importance of accounting for individual events, particularly for the enrichment of SOC in delivered sediment (Fig. 6). However, it should be noted that SOC enrichment is mostly affected by catchment characteristics (Fig. $6 \mathrm{~b}-\mathrm{c}$ ). While catchment $\mathrm{C} 1$ follows the expected behaviour, i.e. decreasing SOC enrichment with increasing event size (Auerswald and Weigand, 1999; Menzel, 1980; Polyakov and Lal, 2004b; Sharpley, 1985), and is in good agreement with the results of Wang et al. (2010) for similar soils in the Belgian loam belt, event size had hardly any effect on the SOC enrichment in catchment $\mathrm{C} 2$, where any larger particles, including aggregates, are deposited in the grassed waterway due to consistently high hydraulic roughness throughout the year. Hence, a parsimonious approach solely relating annual erosion magnitude to SOC enrichment (e.g. Fiener et al., 2015, using the model SPEROS-C) might fail on the landscape scale due to varying inter-field connectivity characteristics of catchments. Underlining the results of recent studies (e.g. Hu and Kuhn, 2016), it seems to be essential to take detailed processes into account during erosion, transport, and deposition in order to accurately capture the SOC enrichment of delivered sediments. In our modelling example, neglecting enrichment would lead to a $36 \%$ underestimation of the total SOC delivery in catchment $\mathrm{C} 1$ and an even more extreme $63 \%$ underestimation in 
catchment $\mathrm{C} 2$. This large difference between catchment $\mathrm{C} 1$ and $\mathrm{C} 2$ suggests that the relevance of SOC enrichment in delivered sediments is controlled not only by event size but also by the catchment connectivity to the outlet.

SOC enrichment in delivered sediments is mainly controlled by the physical properties (e.g. soil texture) of the parent soil (Foster et al., 1985). Soil aggregation transforms unconsolidated fine primary particles, a highly mobile SOC fraction, into soil aggregates, a fraction in which SOC is far less mobile. Hu and Kuhn (2016) showed that soil aggregation reduces the transport distance and potentially enhances terrestrial SOC deposition up to $64 \%$. We found a similar trend: upon increasing the aggregation level of the model from non-aggregated ( $\mathrm{Agg}_{\text {off }}$ ) to heavily aggregated (Agghi) soil conditions, we found an increase in SOC deposition for both catchment $\mathrm{C} 1(47 \%)$ and C2 (83\%). However, while soil texture clearly plays an important role, inter-field connectivity can be the dominant process driving lateral SOC delivery on the landscape scale. This is demonstrated by catchment C2, which shows its largest SOC delivery when it is assumed that there is no soil aggregation. Unfortunately, representing soil aggregation in models is challenging due to a pronounced seasonality (Angers and Mehuys, 1988; Coote et al., 1988; Six et al., 2004; Wang et al., 2010) and complex spatial patterns related to soil nutrients, moisture, grain size distribution, management practices, erosion, and soil biota (Denef et al., 2002). Especially for landscape-scale applications, this high degree of complexity needs to be substantially reduced in a conceptual way. In general, static soil parameters might underestimate dynamic feedbacks, but they are a necessary simplification for landscape-scale modelling approaches.

\subsection{Erosion-induced C balance of different catchments}

Under the same precipitation and field conditions, the simulated erosion-induced $\mathrm{C}$ balance of catchment $\mathrm{C} 1$ and $\mathrm{C} 2$ show opposing results (Fig. 5: Bal1-Bal2). While catchment $\mathrm{C} 1$ acts as a $\mathrm{C}$ source for the majority of simulated processes (controlled primarily by SOC delivery), the presence of the grassed waterway for catchment $\mathrm{C} 2$ substantially reduces lateral SOC delivery and leads the catchment to function as a $\mathrm{C}$ sink for most simulated processes. For both catchments, the majority of simulation years show a positive erosion-induced $\mathrm{C}$ balance (sink). However, three heavy erosion events in catchment $\mathrm{C} 1$ exceeded the positive cumulative vertical flux. Therefore, we underline that any analysis of landscape-scale erosion-induced $\mathrm{C}$ balances must consider inter-field connectivity.

\section{Conclusions}

In this study, the effect of individual SOC redistribution processes on SOC dynamics is assessed by utilizing a coupled process-oriented erosion and $\mathrm{C}$ turnover model. The erosion component of the model was successfully validated against a continuous 8-year data set of surface runoff and sediment delivery. The model was able to estimate the relevance of different processes in terms of their impact on vertical and lateral $\mathrm{C}$ fluxes for two catchments with distinct characteristics over an artificial time series of 50 years. We found that tillage erosion dominates on-field soil redistribution and vertical erosion-induced $\mathrm{C}$ fluxes on arable land, while water erosion processes have a much more limited effect. However, episodic lateral SOC delivery is critically important for the carbon balance. Ignoring SOC enrichment in delivered sediments leads to a pronounced underestimation of delivered SOC. Soil aggregates substantially reduce SOC delivery by turning highly mobile fine primary particles into less mobile soil aggregates. In general, the erosion-induced $\mathrm{C}$ balance is largely affected by inter-field deposition related to catchment connectivity.

Our results underline the importance of having an accurate and spatially distributed representation of tillage erosion. The episodic nature of water erosion calls for a sufficiently long simulation period and the inclusion of grainsize-selective transport in order to address the enrichment of delivered SOC. Furthermore, we stress the need for future investigations on seasonal and spatial variations in soil aggregation for a conceptual model implementation.

Data availability. The MCST-C model is still under development and utilized in current studies. If someone is interested in cooperation, the authors would be happy to share the recent model version and the data used in this study.

Competing interests. The authors declare that they have no conflict of interest.

Acknowledgements. The study was supported by the Terrestrial Environmental Observatory TERENO-Northeast of the Helmholtz Association. We would like to acknowledge the large number of scientists and technicians who collected the data used in this study, which was funded by the Bundesministerium für Bildung, Wissenschaft, Forschung und Technologie (BMBF No. 0339370) and the Bayerische Staatsministerium für Unterricht und Kultus, Wissenschaft und Kunst.

Edited by: N. J. Kuhn

Reviewed by: two anonymous referees

\section{References}

Andrén, O. and Kätterer, T.: ICBM: The introductory carbon balance model for exploration of soil carbon balances, Ecol. Appl., 7, 1226-1236, 1997. 
Angers, D. A. and Mehuys, G. R.: Effects of cropping on macroaggregation of a marine clay soil, Can. J. Soil Sci., 68, 723-732, 1988.

Auerswald, K. and Weigand, S.: Eintrag und Freisetzung von $\mathrm{P}$ durch Erosionsmaterial in Oberflächengewässern, VDLUFASchriftenreihe, 50, 37-54, 1999.

Auerswald, K., Albrecht, H., Kainz, M., and Pfadenhauer, J.: Principles of sustainable land-use systems developed and evaluated by the Munich Research Alliance on agro-ecosystems (FAM), Petermanns Geographische Mitteilungen, 144, 16-25, 2000.

Berhe, A. A., Harte, J., Harden, J. W., and Torn, M. S.: The significance of the erosion-induced terrestrial carbon sink, Bioscience, 57, 337-346, 2007.

Beuselinck, L., Steegen, A., Govers, G., Nachtergaele, J., Takken, I., and Poesen, J.: Characteristics of sediment deposits formed by intense rainfall events in small catchments in the Belgian Loam Belt, Geomorphology, 32, 69-82, 2000.

Casagrande, A.: Die Aräometermethode zur Bestimmung der Korngrößenverteilung von Böden, Arthur Casagrande, Berlin, 1934.

Coote, D. R., Malcolm-McGovern, C. A., Wall, G. J., Dickinson, W. T., and Rudra, R. P.: Seasonal variation of erodibility indices based on shear strength and aggregate stability in some Ontario soils, Can. J. Soil Sci., 68, 405-416, 1988.

Denef, K., Six, J., Merckx, R., and Paustian, K.: Short-term effects of biological and physical forces on aggregate formation in soils with different clay mineralogy, Plant Soil, 246, 185-200, 2002.

DIN: DIN ISO 11277: 2002-08 Bodenbeschaffenheit - Bestimmung der Partikelgrößenverteilung in Mineralböden - Verfahren mittels Siebung und Sedimentation, Beuth Verlag, Berlin, 2002.

Dlugoß, V., Fiener, P., Van Oost, K., and Schneider, K.: Model based analysis of lateral and vertical soil $\mathrm{C}$ fluxes induced by soil redistribution processes in a small agricultural watershed, Earth Surf. Proc. Land., 37, 193-208, 2012.

Doetterl, S., Six, J., Van Wesemael, B., and Van Oost, K.: Carbon cycling in eroding landscapes: geomorphic controls on soil organic C pool composition and C stabilization, Glob. Change Biol., 18, 2218-2232, 2012.

Doetterl, S., Berhe, A. A., Nadeu, E., Wang, Z., Sommer, M., and Fiener, P.: Erosion, deposition and soil carbon: A review on process-level controls, experimental tools and models to address C cycling in dynamic landscapes, Earth-Sci. Rev., 154, 102-122, 2016.

Fiener, P. and Auerswald, K.: Effectiveness of grassed waterways in reducing runoff and sediment delivery from agricultural watersheds, J. Environ. Qual., 32, 927-936, 2003.

Fiener, P. and Auerswald, K.: Möglichkeiten der Abfluss- und Stofftransportkontrolle durch landwirtschaftliche Maßnahmen und ihre Kombination im Landschaftsmaßstab, in: DWA Sonderdruck zum Tag der Hydrologie 2007, Rostock, 23-36, 2007a.

Fiener, P. and Auerswald, K.: Rotation effects of potato, maize and winter wheat on soil erosion by water, Soil Sci. Soc. Am. J., 71, 1919-1925, 2007b.

Fiener, P., Govers, G., and Van Oost, K.: Evaluation of a dynamic multi-class sediment transport model in a catchment under soilconservation agriculture, Earth Surf. Processes Landforms, 33, 1639-1660, 2008.

Fiener, P., Dlugoß, V., and Van Oost, K.: Erosion-induced carbon redistribution, burial and mineralisation - Is the episodic nature of erosion processes important?, Catena, 133, 282-292, 2015.
Foster, G. R., Young, R. A., and Neibling, W. H.: Sediment composition for nonpoint source pollution analyses, Transactions of the American Society of Agricultural Engineers, 28, 133-139, 1985.

Friedlingstein, P., Andrew, R. M., Rogelj, J., Peters, G. P., Canadell, J. G., Knutti, R., Luderer, G., Raupach, M. R., Schaeffer, M., van Vuuren, D. P., and Le Quere, C.: Persistent growth of $\mathrm{CO}_{2}$ emissions and implications for reaching climate targets, Nat. Geosci., 7, 709-715, 2014.

Giménez, R. and Govers, G.: Flow detachment by concentrated flow on smooth and irregular beds, Soil Sci. Soc. Am. J., 66, 14751483, 2002.

Govers, G., Vandaele, K., Desmet, P., Poesen, J., and Bunte, K.: The role of tillage in soil redistribution on hillslopes, Eur. J. Soil Sci., 45, 469-478, 1994.

Hairsine, P. B. and Rose, C. W.: Rainfall detachment and deposition: Sediment transport in the absence of flow-driven processes, Soil Sci. Soc. Am. J., 55, 320-324, 1991.

Hairsine, P. B., Moran, C. J., and Rose, C. W.: Recent developments regarding the influence of soil surface characteristics on overland flow and erosion, Aust. J. Soil Res., 30, 249-264, 1992.

Hiederer, R. and Köchy, M.: Global Soil Organic Carbon Estimates and the Harmonized World Soil Database, Publications Office of the EU, Luxenbourg, 2011.

Hooke, R. L.: On the history of humans as geomorphic agents, Geology, 28, 843-846, 2000.

$\mathrm{Hu}$, Y. and Kuhn, N. J.: Aggregates reduce transport distance of soil organic carbon: are our balances correct?, Biogeosciences, 11, 6209-6219, doi:10.5194/bg-11-6209-2014, 2014.

$\mathrm{Hu}$, Y. X. and Kuhn, N. J.: Erosion-induced exposure of SOC to mineralization in aggregated sediment, Catena, 137, 517-525, 2016.

Hu, Y. X., Berhe, A. A., Fogel, M. L., Heckrath, G. J., and Kuhn, N. J.: Transport-distance specific SOC distribution: Does it skew erosion induced C fluxes?, Biogeochemistry, 128, 339351, 2016.

Kätterer, T. and Andrén, O.: The ICBM family of analytically solved models of soil carbon, nitrogen and microbial biomass dynamics descriptions and application examples, Ecol. Model., 136, 191-207, 2001.

Kirkels, F. M. S. A., Cammeraat, L. H., and Kuhn, N. J.: The fate of soil organic carbon upon erosion, transport and deposition in agricultural landscapes - A review of different concepts, Geomorphology, 226, 94-105, 2014.

Lacoste, M., Viaud, V., Michot, D., and Walter, C.: Landscape-scale modelling of erosion processes and soil carbon dynamics under land-use and climate change in agroecosystems, Eur. J. Soil Sci., 66, 780-791, 2015.

Legout, C., Leguédois, S., and Le Bissonnais, Y.: Aggregate breakdown dynamics under rainfall compared with aggregate stability measurements, Eur. J. Soil Sci., 56, 225-237, 2005.

Menzel, R. G.: Enrichment ratios for water quality modeling, in: CREAMS, edited by: Knisel, W. G., USDA Cons. Res. Rep., 1980.

Myers, N.: Gaia: An atlas of planet management, Anchor Press, Garden City, 1993.

Nadeu, E., Gobin, A., Fiener, P., Van Wesemael, B., and Van Oost, K.: Modelling the impact of agricultural management on soil carbon stocks at the regional scale: the role of lateral fluxes, Glob. Change Biol., 21, 3181-3192, 2015. 
Nash, J. E. and Sutcliffe, J. V.: River flow forecasting through conceptual models: Part I. A discussion of principles, J. Hydrol., 10, 282-290, 1970.

Oades, J. M.: Soil organic matter and structural stability: mechanisms and implications for management, Plant Soil, 76, 319-337, 1984.

Oades, J. M. and Waters, A. G.: Aggregate hierachy in soils, Aust. J. Soil Res., 29, 815-828, 1991.

Pimentel, D., Harvey, C., Resosudarmo, P., Sinclair, K., Kurz, D., McNair, M., Crist, S., Shpritz, L., Fitton, L., Saffouri, R., and Blair, R.: Environmental and economic costs of soil erosion and conservation benefits, Science, 267, 1117-1123, 1995.

Polyakov, V. and Lal, R.: Modeling soil organic matter dynamics as affected by soil water erosion, Environ. Int., 30, 547-556, $2004 \mathrm{a}$.

Polyakov, V. O. and Lal, R.: Soil erosion and carbon dynamics under simulated rainfall, Soil Sci., 169, 590-599, 2004b.

Prechtel, A., von Lützow, M., Schneider, B. U., Bens, O., Bannick, C. G., Kögel-Knabner, I., and Hüttl, R. F.: Organic carbon in soils of Germany: Status quo and the need for new data to evaluate potentials and trends of soil carbon sequestration, J. Plant Nutr. Soil Sci., 172, 601-614, 2009.

Renard, K. G., Foster, G. R., Weesies, G. A., McCool, D. K., and Yoder, D. C.: Predicting soil erosion by water: A guide to conservation planning with the Revised Universal Soil Loss Equation (RUSLE), USDA-ARS, Washington DC, 1996.

Scheinost, A. C., Sinowski, W., and Auerswald, K.: Regionalization of soil water retention curves in a highly variable soilscape, I. Developing a new pedotransfer function, Geoderma, 78, 129-143, 1997.

Schiettecatte, W., Gabriels, D., Cornelis, W. M., and Hofman, G.: Enrichment of organic carbon in sediment transport by interrill and rill erosion processes, Soil Sci. Soc. Am. J., 72, 50-55, 2008.

Sharpley, A. N.: The selective erosion of plant nutrients in runoff, Soil Sci. Soc. Am. J., 49, 1527-1534, 1985.

Sinowski, W. and Auerswald, K.: Using relief parameters in a discriminant analysis to stratify geological areas with different spatial variability of soil properties, Geoderma, 89, 113-128, 1999.

Sinowski, W., Scheinost, A. C., and Auerswald, K.: Regionalization of soil water retention curves in a highly variable soilscape, II. Comparison of regionalization procedures using a pedotransfer function, Geoderma, 78, 145-159, 1997.

Six, J., Conant, R. T., Paul, E. A., and Paustian, K.: Stabilization mechanisms of soil organic matter: implications for C-saturation of soils, Plant Soil, 241, 155-176, 2002.

Six, J., Bossuyt, H., Degryze, S., and Denef, K.: A history of research on the link between (micro)aggregates, soil biota, and soil organic matter dynamics, Soil Till. Res., 79, 7-31, 2004.

Tisdall, J. M. and Oades, J. M.: Organic matter and water-stable aggregates in soils, J. Soil Sci., 33, 141-163, 1982.

Van Hemelryck, H., Fiener, P., Van Oost, K., Govers, G., and Merckx, R.: The effect of soil redistribution on soil organic carbon: an experimental study, Biogeosciences, 7, 3971-3986, doi:10.5194/bg-7-3971-2010, 2010.
Van Hemelryck, H., Govers, G., Van Oost, K., and Merckx, R.: Evaluating the impact of soil redistribution on the in situ mineralization of soil organic carbon, Earth Surf. Proc. Land., 36, 427-438, 2011.

Van Muysen, W., Govers, G., Van Oost, K., and Van Rompaey, A.: The effect of tillage depth, tillage speed, and soil condition on chisel tillage erosivity, J. Soil Water Conserv., 55, 2-11, 2000.

Van Oost, K. and Govers, G.: Tillage erosion, in: Soil erosion in Europe, edited by: Boardman, J. and Poesen, J., Wiley, Chichester, 2006.

Van Oost, K., Beuselinck, L., Hairsine, P. B., and Govers, G.: Spatial evaluation of a multi-class sediment transport and deposition model, Earth Surf. Proc. Land., 29, 1027-1044, 2004.

Van Oost, K., Govers, G., Quine, T., Heckarth, G., Olesen, J. E., De Gryze, S., and Merckx, R.: Landscape-scale modeling of carbon cycling under the impact of soil redistribution: The role of tillage erosion, Global Biogeochem. Cy., 19, GB4014, doi:10.1029/2005GB002471, 2005a.

Van Oost, K., Quine, T., Govers, G., and Heckrath, G.: Modeling soil erosion induced carbon fluxes between soil and atmosphere on agricultural land using SPEROS-C, in: Advances in soil science. Soil erosion and carbon dynamics, edited by: Roose, E. J., Lal, R., Feller, C., Barthes, B., and Stewart, B. A., CRC Press, Boca Raton, 2005b.

Van Oost, K., Govers, G., De Alba, S., and Quine, T. A.: Tillage erosion: a review of controlling factors and implications for soil quality, Prog. Phys. Geogr., 30, 443-466, 2006.

Von Lützow, M., Kögel-Knabner, I., Ekschmitt, K., Flessa, H., Guggenberger, G., Matzner, E., and Marschner, B.: SOM fractionation methods: Relevance to functional pools and to stabilization mechanisms, Soil Biol. Biochem., 39, 2183-2207, 2007.

Wang, X., Cammeraat, L. H., Wang, Z., Zhou, J., Govers, G., and Kalbitz, K.: Stability of organic matter in soils of the belgian loess belt upon erosion and deposition, Eur. J. Soil Sci., 64, 219228, 2013.

Wang, Z., Govers, G., Steegen, A., Clymans, W., Van den Putte, A., Langhans, C., Merckx, R., and Van Oost, K.: Catchment-scale carbon redistribution and delivery by water erosion in an intensively cultivated area, Geomorphology, 124, 65-74, 2010.

Wilken, F., Fiener, P., and Van Oost, K.: Modelling a century of soil redistribution processes and carbon delivery from small watersheds using a multi-class sediment transport model, Earth Surf. Dynam., 5, 113-124, 2017.

Wilkinson, B. H. and McElroy, B. J.: The impact of humans on continental erosion and sedimentation, Geol. Soc. Am. Bull., 119, 140-156, 2007. 